\section{Childhood anemia prevalence and associated factors in Salvador, Bahia, Brazil}

\author{
Prevalência e fatores associados \\ à ocorrência da anemia em pré-escolares \\ na cidade de Salvador, Bahia, Brasil
}

\author{
Ana Marlúcia O. Assis ${ }^{1}$ \\ Mauricio L. Barreto 2 \\ Gecynalda Soares da Silva Gomes 1 \\ Matildes da Silva Prado 1 \\ Nedja Silva dos Santos 1 \\ Leonor Maria Pacheco Santos 3 \\ Lílian Ramos Sampaio 1 \\ Rita de Cássia Ribeiro ${ }^{1}$ \\ Lucivalda Pereira Magalhães de Oliveira 1 \\ Valterlinda Alves de Oliveira 1
}

1 Escola de Nutrição, Universidade Federal da Bahia, Salvador, Brasil.

2 Instituto de Saúde Coletiva,

Universidade Federal da Bahia, Salvador, Brasil.

3 Faculdade de Ciências da Saúde, Universidade de Brasília, Brasília, Brasil.

Correspondence A. M. O. Assis

Escola de Nutrição, Universidade Federal da Bahia. Rua Araújo Pinho 32, Salvador, BA 40110-150, Brasil amos@ufba.br

\begin{abstract}
A cross-sectional study was conducted in 1996 to estimate the prevalence of anemia in a stratified sample of 603 preschool children and identify factors associated with the disease. Hemoglobin assays were conducted in finger-prick blood samples using a Hemocue hemoglobinometer. Anemia was defined as hemoglobin below $11.0 \mathrm{~g} / \mathrm{dl}$. Logistic regression analysis was used to evaluate the potential associations. Observed anemia prevalence was $46.3 \%$. Associated factors were: the 6-12-month and 12-24-month age brackets, the lowest tertiles for iron density and protein content dietary intake, and any degree of deficit in the height-for-age anthropometric parameter. Inadequate physical, sanitary, and environmental conditions in the home were associated with a significantly increased risk of anemia. Anemia constitutes an important health problem in this study's child population. Improvements in living conditions and dietary quality could contribute to a reduction in anemia prevalence.
\end{abstract}

Anemia; Preschool Child; Logistic Models

\section{Introduction}

Anemia is a highly frequent disease worldwide. It affects individuals in all stages of life, although preschool children and pregnant women are the most heavily affected. The highest prevalence rates are observed in these two groups in underdeveloped countries, but these rates are also high in developed countries 1 .

Although there are no population-based data to characterize the distribution and magnitude of anemia in Brazil, studies from representative samples of population segments in various areas of the country 2,3 indicate that anemia is highly prevalent among preschool children. This period of life is characterized by rapid growth, which increases the demand for iron; if the micronutrient balance becomes negative, the disease can develop 4 . Various factors are associated with the occurrence of anemia, amongst which genetic causes, parasitic and infectious diseases, and other micronutrient deficiencies, in addition to low consumption of iron-rich food and high intake of iron absorption inhibitors or iron-chelating substances 5 . Inadequate social and economic conditions for the child and family are particularly important factors 6 . However, the evidence indicates that if anemia prevalence is high, the most probable cause is dietary iron deficiency 5 . Thus, at the population level, anemia has been used as a proxy for the prevalence of iron deficiency 1 . 
Considering anemia's negative effects on preschool physical growth, psychomotor development, and learning 1 , as well as on the immune system's response capacity 5 , this study was planned to identify the anemia prevalence and factors associated with the disease in a representative sample of preschool children in the city of Salvador, Bahia, Brazil. The results of this study may contribute for the definition of measures to combat the disease in the pursuit of an adequate child health and nutrition.

\section{Population and method}

\section{Study design and population}

The study included 603 preschool children from the city of Salvador, part of a larger investigation that was planned to evaluate the nutritional status and living conditions in this population segment 7 .

The sample size in this study was estimated on the basis of a $20 \%$ prevalence rate for anemia. Thirty census tracts were selected 8 , distributed randomly among the four zones in which the city was mapped, according to the Living Conditions Index proposed by Paim 9. In each census tract, sixty households were visited and approximately six hundred children were selected, one in each household, including an additional 5\% to cover occasional losses. A threestage cluster sampling strategy was thus adopted in which the census tract was the primary selection unit, the household was the secondary unit, and the child was the tertiary unit.

\section{Data collection}

Data collection was performed from October to November 1996 by trained interviewers and supervised by the researchers. The information was provided by the child's mother or guardian.

\section{Laboratory assessment}

Blood samples were taken by the finger prick technique, using disposable lancets. A portable hemoglobinometer (Hemocue, Laguna Hills) 5 was used to determine the hemoglobin concentration. A second measurement was performed when the hemoglobin level was $<9 \mathrm{~g} / \mathrm{dl}$, and the mean of the two measurements was adopted as the final value.

\section{Food consumption}

Information on 24-hour food intake relates to the period from Tuesday through Saturday, thus avoiding recording weekend food consumption, which normally does not reflect the daily diet 10 . An album with drawings of foods and standard measurements of liquids was used for the interviewer to recall the size of the portions served 11. This information was processed using Virtual Nutri, version 1.

\section{Anthropometric data}

The children were weighed unclothed or using a minimum of clothing, with a microelectronic scale (Fillizola), provided on loan by the former Brazilian National Institute of Food and Nutrition. The children's length and height were measured, respectively, with a portable wooden infantometer and stadiometer 12. Variations of $100 \mathrm{~g}$ and $0.1 \mathrm{~cm}$ were accepted, respectively, for weight and length/height. The date of birth was recorded from the birth certificate and birth weight from the child's or maternity hospital's card. Anthropometric measurements were standardized as recommended by the World Health Organization (WHO) 12.

\section{Socioeconomic and environmental data}

These data relate to the family's social and environmental conditions and the household's physical conditions and sanitation.

\section{Reported morbidity}

The morbidity pattern was based on the symptoms and/or complaints reported by the mother and/or guardian and relates to the two weeks prior to the interview. Hospital admissions for any reason refer to the 12 months prior to the interview.

\section{Ethical aspects}

The child's inclusion in the study was conditioned on the mother or guardian's verbal consent. Any diagnosis of anemia and severe malnutrition was communicated immediately to the mother or guardian, and the child was referred to the health service for pediatric treatment and also to the Nutrition Service of the Health Unit belonging to the Program for Treatment of the Malnourished.

\section{Data analysis}

Anemia was defined in children from 6 to 72 months of age as hemoglobin $<11.0 \mathrm{~g} / \mathrm{dl} 5$. Due to the lack of a similar standard, the same cutoff point was adopted for children $<6$ months 
of age, which is accepted in clinical practice 13 . Hemoglobin $\geq 11.0 \mathrm{~g} / \mathrm{dl}$ was considered normal. This classification was used in the logistic regression analysis, and the variable was adopted as dependent. To describe the event in the population, anemia was further classified as mild/ moderate (hemoglobin from 9.5 to $10.9 \mathrm{~g} / \mathrm{dl}$ ) and severe $(<9.5 \mathrm{~g} / \mathrm{dl})$.

Key explanatory variables included the height-for-age and weight-for-age anthropometric indicators. This study used the cutoff point of $<-1$ SD from the population reference mean of the National Center for Health Statistics (NCHS) 14 to characterize an anthropometric deficit and $\geq-1 S D$ to characterize eutrophy.

The aim was thus to identify the association between anemia and any degree of malnutrition, and not merely the severe and moderate forms. The authors agree with the concern expressed by WHO experts 15 , that the identification of determinants of childhood malnutrition should focus on defining measures to best improve children's health and nutritional conditions, and that the most important impact of these measures occurs when all children at risk of malnutrition are contemplated, rather than only those whose malnutrition is situated $<-2 \mathrm{SD}$ from the $z$-score, the accepted cutoff point for identifying severe and moderate malnutrition and for defining measures to treat malnourished children. In addition, the impact of malnutrition on mortality is not limited to the severe and moderate forms. The mild form makes a major contribution to mortality 16 , and its attributable risk is $46.0 \%$ to $93.0 \%$ for preschool children in poor countries 17.

This range of variables also includes those related to household physical conditions (type of flooring, walls, and number of rooms), environmental and sanitary conditions (source of drinking water, forms of garbage storage, type of sewerage, and toilet facilities), and health/ sanitary conditions of the environmental peridomestic. These variables constituted an index adapted to the Issler \& Giugliani model 18, built by the sum of the points for each variable and grouped in tertiles.

As a further condition associated with the family environment, the model considered the number of inhabitants per bedroom, classified as 1 to 2 (taken as the reference) as compared to the other categories ( 3 to $4 ; 5$ to 6 ; and $>6$ ), interpreted as increasing risk.

The dietary variables are represented by dietary calories (classified in quartiles), by the amount of iron and protein categorized in tertiles, and by dietary iron density, which was calculated by dividing the amount of this mi- cronutrient per $100 \mathrm{kcal}$ of the diet and subsequently classified in tertiles.

The head-of-family's age was categorized as 14 to $25 ; 25$ to 65 ; and $>65$ years. The 25 to 65 year age bracket was taken as the reference. The child's age was categorized based on the critical periods for anemia and for changes in eating patterns ( 0 to 6,6 to 12,12 to 24 ; and 24 to 60 months, with 0 to 6 months as the reference). Male gender was taken as protective for both children and heads of family.

Birth weight was classified as $<2500 \mathrm{~g}$ and $\geq$ $2500 \mathrm{~g}$ (reference) and morbidity and hospitalization was categorized as 0 and 1 . Whenever indicated the variables were transformed into their respective dummies.

Considering that the sampling design for this study involved a three-stage cluster structure, a weighting of the statistical analysis was adopted to incorporate the clustering effect in the inferences and standard error of the estimates and to designate the relative importance of the elements in the sample population 19 . For weighting purposes, the sample weight was adopted, which was calculated as the inverse of the probability of the child being selected.

The EpiInfo CSAMPLE module was used to estimate prevalence. Logistic regression was adopted to evaluate the associations of interest. Backward-type regression was used for selection of variables. A $20 \%$ significance level was used to introduce the variable in the model and a 5\% level was used to maintain the variable in the model. The Stata program was used for these procedures.

\section{Results}

The hemoglobin measurement performed in 603 preschool children led to the diagnosis of $46.3 \%$ (95\%CI: $42.3 \%-50.3 \%$ ) as anemic, with a differentiated distribution according to age ( $p$ $<0.001)$. Anemia was less frequent in children from 0 to 6 months, increased from 6 to 24 months, and dropped again progressively with age. Severe anemia (hemoglobin $<9.5 \mathrm{~g} / \mathrm{dl}$ ) was identified in $13.5 \%$ of the children in the sample (Table 1).

Table 2 shows the bivariate analysis parameters. Children from 12 to 24 months of age had 1.94 (95\%CI: 1.07-3.51) the odds of presenting anemia as compared to those under six months, a risk that increased slightly $(\mathrm{OR}=1.99$; 95\%CI: 1.01-3.94) in children from 6 to 12 months of age. When the head of the family was 65 years of age or over, the odds of the child presenting anemia was $63.0 \%$ less as compared to 
Prevalence of anemia in preschool children. Salvador, Bahia, Brazil, 1996.

\begin{tabular}{|c|c|c|c|c|c|c|c|}
\hline \multirow[t]{2}{*}{$\mathrm{Age}^{\star}$ (months) } & \multirow[t]{2}{*}{$\begin{array}{l}\text { Number of } \\
\text { children }\end{array}$} & $(\mathrm{Hb}$ & $\begin{array}{l}\text { ere } \\
.5 \mathrm{~g} / \mathrm{dl})\end{array}$ & \multicolumn{2}{|c|}{$\begin{array}{c}\text { Anemia } \\
\text { Mild/moderate } \\
(\mathrm{Hb} 9.5-11.0 \mathrm{~g} / \mathrm{dl})\end{array}$} & \multicolumn{2}{|c|}{$\begin{array}{c}\text { Total } \\
(\mathrm{Hb}<11.0 \mathrm{~g} / \mathrm{dl})\end{array}$} \\
\hline & & $\mathrm{n}$ & $\%$ & $\mathrm{n}$ & $\%$ & $\mathrm{n}$ & $\%$ \\
\hline $0-6$ & 56 & 6 & 10.7 & 22 & 39.3 & 28 & 50.0 \\
\hline $6-12$ & 76 & 23 & 30.3 & 26 & 34.2 & 49 & 64.5 \\
\hline $12-24$ & 137 & 27 & 19.7 & 61 & 44.5 & 88 & 64.2 \\
\hline $24-36$ & 122 & 13 & 10.7 & 41 & 33.6 & 54 & 44.3 \\
\hline $36-60$ & 212 & 13 & 6.1 & 47 & 22.2 & 60 & 28.3 \\
\hline Total & 603 & 82 & 13.5 & 197 & 32.8 & 279 & 46.3 \\
\hline
\end{tabular}

* Anemia was distributed differently according to the child's age $(p<0.001)$;

$\mathrm{n}=$ number of children; $\mathrm{Hb}=$ hemoglobin.

heads of family 25 to 65 years of age $(\mathrm{OR}=0.37$; 95\%CI: 0.17-0.79).

A dietary iron density of $\leq 0.4 \mathrm{mg} / 100 \mathrm{kcal}_{\mathrm{th}}$ conferred an odds ratio of 1.69 (95\%CI: 1.11 2.56) for the child to present anemia as compared to $>0.6 \mathrm{mg} / 100 \mathrm{kcal}_{\mathrm{th}}$. Furthermore, the odds of anemia were 1.53 (95\%CI: 1.02-2.30) when iron consumption was located in the lowest tertile ( $\leq 4.2 \mathrm{mg} /$ day), as compared to the highest tertile ( $\geq 7.3 \mathrm{mg} /$ day).

Mean daily protein intake $\leq 28.8 \mathrm{~g}$ conferred an increased risk of anemia $(\mathrm{OR}=1.53 ; 95 \% \mathrm{CI}$ : 1.05-2.23), as compared to a protein intake of greater than $44.6 \mathrm{~g} /$ day.

Table 3 shows the adjusted parameters in the logistic regression model for anemia. After adjusting the model, it was observed that the risk of anemia by age was increased and that children from 6 to 12 months of age showed an increased risk (OR $=5.35$; 95\%CI: $1.73-16.58$ ) as compared to those in the 12 to 24 month bracket $(\mathrm{OR}=4.78 ; 95 \% \mathrm{CI}: 1.97-11.57)$. Children whose dietary iron density was $\leq 0.4 \mathrm{mg} / 100 \mathrm{kcal}_{\text {th }}$ had a 3.11 greater odds of anemia (95\%CI: 1.13-8.58) than those whose iron density was $>0.6 \mathrm{mg} /$ $100 \mathrm{kcal}_{\mathrm{th}}$. Likewise, a protein intake of $\leq 28.8 \mathrm{~g}$ led to 2.35 odds of anemia (95\%CI: 1.10-5.02) as compared to the highest tertile in the distribution ( $>44.6 \mathrm{~g} / \mathrm{dia})$.

After adjusting the model, children whose height-for-age index was below - $1 z$-score had an increased odds of developing anemia as compared to those with the index greater than or equal to $-1 z$-score (OR $=2.19$; 95\%CI: $1.07-4.45$ ).

Finally, the odds of the child presenting anemia increased as the household physical, environmental, and sanitary conditions became more precarious. Children living in households with only "fair" physical, environmental, and sanitary conditions had odds of 1.70 (95\%CI: 1.10-2.61) of presenting anemia. The odds increased to 2.09 (95\%CI: 1.22-3.60) in the presence of precarious conditions, as compared to children living in households with adequate physical, environmental, and sanitary conditions.

\section{Discussion}

According to this study, prevalence of anemia in preschool children in Salvador, Bahia, Brazil $(46.3 \%)$ was higher than the WHO definition 5 ( $\geq 40 \%$ ) for characterizing the disease as a major health problem for this population group. The prevalence observed in Bahian children (46.3\%) in 1996 was similar to that identified in the city of São Paulo (46.9\%) that same year 3 and in Recife, Pernambuco State $(46.4 \%)$ in 19972 for children under five years of age.

The child's age was associated significantly with the occurrence of anemia; the risk was higher among children 6 to 12 months, decreasingly slightly from 12 to 24 months. These age range, significantly associated with anemia, are the same in which the most important changes occur in child-feeding regimens, namely weaning, complementary foods and exposure to the family unit's eating patterns. The short median duration of exclusive and total breastfeeding, along with the low iron content in complementary foods in children under two years of age in this study 7 may partially explain these increased risks. For these children, breastfeeding and especially prolonged breastfeeding are important strategies for preventing anemia, given the high bioavailability of iron in human breast milk (50.0\%) 5 . 
Unadjusted odds ratio for the association between anemia and biological, nutritional, social, and environmental variables in preschool children. Salvador, Bahia, Brazil, 1996.

\begin{tabular}{|c|c|c|c|c|c|}
\hline \multirow[t]{2}{*}{ Variables } & \multirow[t]{2}{*}{$\mathrm{n}$} & \multirow[t]{2}{*}{$\%$} & \multicolumn{3}{|c|}{ Anemia } \\
\hline & & & gross OR & $95 \% \mathrm{Cl}$ & p-value \\
\hline \multicolumn{6}{|l|}{ Age (months) } \\
\hline $0-6$ & 55 & 9.6 & 1.00 & - & - \\
\hline $6-12$ & 75 & 12.4 & 1.99 & $1.01-3.94$ & 0.047 \\
\hline $12-24$ & 133 & 23.2 & 1.94 & $107-3.51$ & 0.030 \\
\hline $24-60$ & 328 & 54.8 & 0.57 & $0.30-1.06$ & 0.074 \\
\hline \multicolumn{6}{|l|}{ Child's gender } \\
\hline Male & 291 & 49.4 & 1.00 & - & - \\
\hline Female & 300 & 50.6 & 0.91 & $0.69-119$ & 0.466 \\
\hline \multicolumn{6}{|l|}{ Birth weight (g) } \\
\hline$\geq 2,500$ & 452 & 76.6 & 1.00 & - & - \\
\hline$<2,500$ & 129 & 23.4 & 0.82 & $0.49-1.37$ & 0.437 \\
\hline \multicolumn{6}{|c|}{ Presence of disease ${ }^{\star}$} \\
\hline No & 369 & 62.7 & 1.00 & - & - \\
\hline Yes & 217 & 37.3 & 1.16 & $0.80-1.68$ & 0.437 \\
\hline \multicolumn{6}{|c|}{$\begin{array}{l}\text { Hospitalization during the year } \\
\text { preceding the interview }\end{array}$} \\
\hline No & 492 & 85.1 & 1.00 & & \\
\hline Yes & 85 & 14.9 & 1.46 & $0.96-2.23$ & 0.078 \\
\hline \multicolumn{6}{|c|}{ Height-for-age indicator } \\
\hline$\geq-1$ (z score) & 487 & 82.4 & 1.00 & & \\
\hline$<-1$ (z score) & 104 & 17.6 & 1.40 & $0.85-2.33$ & 0.181 \\
\hline \multicolumn{6}{|c|}{ Weight-for-age indicator } \\
\hline$\geq-1$ (z score) & 470 & 79.8 & 1.00 & & \\
\hline$<-1$ (z score) & 121 & 20.2 & 0.90 & $0.56-1.47$ & 0.672 \\
\hline \multicolumn{6}{|c|}{ Gender, head of family } \\
\hline Male & 456 & 78.0 & 1.00 & - & - \\
\hline Female & 128 & 22.0 & 1.20 & $0.78-1.82$ & 0.407 \\
\hline \multicolumn{6}{|c|}{ Age, head of family (years) } \\
\hline $25-65$ & 382 & 65.6 & 1.00 & - & - \\
\hline $14-25$ & 149 & 25.4 & 1.10 & $0.70-1.72$ & 0.682 \\
\hline Over 65 & 52 & 9.0 & 0.37 & $0.17-0.79$ & 0.011 \\
\hline \multicolumn{6}{|c|}{ Dietary iron density $(\mathrm{mg} / 100 \mathrm{kcal})^{\star \star}$} \\
\hline$>0.6$ & 198 & 34.5 & 1.00 & & \\
\hline $0.6-0.4$ & 214 & 38.0 & 1.09 & $0.71-1.67$ & 0.697 \\
\hline$\leq 0.4$ & 158 & 27.5 & 1.69 & $1.11-2.56$ & 0.015 \\
\hline \multicolumn{6}{|c|}{ Distribution of dietary iron content $(\mathrm{mg} / \mathrm{day})^{\star \star}$} \\
\hline$>7.3$ & 190 & 33.2 & 1.00 & & \\
\hline $4.3-7.3$ & 207 & 36.5 & 1.17 & $0.82-1.67$ & 0.383 \\
\hline$\leq 4.2$ & 173 & 30.3 & 1.53 & $1.02-2.30$ & 0.039 \\
\hline
\end{tabular}

(continues) 


\begin{tabular}{|c|c|c|c|c|c|}
\hline \multirow[t]{2}{*}{ Variables } & \multirow[t]{2}{*}{ n } & \multirow[t]{2}{*}{$\%$} & \multicolumn{3}{|c|}{ Anemia } \\
\hline & & & gross OR & $95 \% \mathrm{Cl}$ & $\mathrm{p}$-value \\
\hline \multicolumn{6}{|c|}{ Distribution, dietary protein content $(\mathrm{g} / \text { day })^{\star *}$} \\
\hline$>44.6$ & 182 & 32.0 & 1.00 & - & - \\
\hline $44.6-28.9$ & 191 & 33.6 & 1.20 & $0.73-1.97$ & 0.470 \\
\hline$\leq 28.8$ & 197 & 34.4 & 1.53 & $1.05-2.23$ & 0.027 \\
\hline \multicolumn{6}{|c|}{ Distribution, dietary calorie content $(\mathrm{kcal} / \text { day })^{\star \star \star}$} \\
\hline$>1,461.8$ & 138 & 24.4 & 1.00 & - & - \\
\hline $1,461.8-1,131.8$ & 133 & 22.9 & 1.39 & $0.83-2.32$ & 0.205 \\
\hline $1,131.9-828.9$ & 147 & 26.0 & 1.00 & $0.64-1.55$ & 0.985 \\
\hline$\leq 828.8$ & 152 & 26.7 & 1.26 & $0.81-1.95$ & 0.291 \\
\hline \multicolumn{6}{|c|}{$\begin{array}{l}\text { Per capita family income (times monthly } \\
\text { minimum wage) }\end{array}$} \\
\hline$>166.7$ & 90 & 20.6 & 1.00 & - & - \\
\hline $166.7-68.9$ & 126 & 28.0 & 0.86 & $0.50-1.48$ & 0.580 \\
\hline $68.8-35.9$ & 117 & 25.5 & 1.18 & $0.62-2.25$ & 0.602 \\
\hline$\leq 358$ & 114 & 25.8 & 1.26 & $0.71-2.23$ & 0.418 \\
\hline \multicolumn{6}{|c|}{$\begin{array}{l}\text { Index of household physical, environmental, } \\
\text { and sanitary conditions }\end{array}$} \\
\hline Good & 192 & 31.8 & 1.00 & - & - \\
\hline Fair & 217 & 36.8 & 1.32 & $0.92-1.90$ & 0.125 \\
\hline Precarious & 182 & 31.4 & 1.47 & $0.92-2.37$ & 0.106 \\
\hline \multicolumn{6}{|c|}{ Number of inhabitants per bedroom } \\
\hline $1-2$ & 203 & 35.0 & 1.00 & - & - \\
\hline $3-4$ & 277 & 47.6 & 1.30 & $0.84-2.02$ & 0.231 \\
\hline$>5$ & 99 & 17.4 & 1.33 & $0.86-2.06$ & 0.188 \\
\hline
\end{tabular}

* in the 15 days prior to the interview; ${ }^{* \star}$ in tertiles; ${ }^{\star \star *}$ in quartiles;

$\mathrm{n}=$ number of children; $\mathrm{OR}=$ odds ratio; $95 \% \mathrm{Cl}=95 \%$ confidence interval.

The diets that these children were exposed to may be reflected in the high anemia rates, particularly because of the low iron content, especially heme iron, and rich in phytates and poor in non-heme iron absorption activators like vitamin C. Such eating practices are known to facilitate the development of anemia 1 .

According to the WHO, if anemia prevalence is greater than $40.0 \%$, the most probable cause is iron-deficient diet 5 . In this study, dietary iron density $\leq 0.4 \mathrm{mg} / 100 \mathrm{kcal}_{\text {th }}$ was associated significantly with anemia in the children, as compared to $>0.6 \mathrm{mg} / 100 \mathrm{kcal}_{\text {th }}$ dietary iron density.

In the first two years of life, iron density in complementary foods should be approximately $0.8 \mathrm{mg} / 100 \mathrm{kcal}_{\mathrm{th}}{ }^{20}$. Offering children highly diluted food and low iron content can limit this density. Regardless of age, mean iron intake for children in this study was $6.0 \mathrm{mg} /$ day, and only one third of the children had diets with an availability of $\geq 6.0 \mathrm{mg} /$ day, thus indicating the limited adequacy of dietary iron. Another key dietary factor associated with anemia was protein intake $\leq 28.8 \mathrm{~g} /$ day as compared to > $44.6 \mathrm{~g} /$ day. According to the WHO 20, not only iron, but also protein, zinc, folic acid, and vitamins $A, B_{12}$, and $C$ among others are necessary for hematopoiesis.

Adjusting the model for the other variables highlighted the statistical importance of the association between anemia and inadequacy of the height-for-age indicator, below $<-1 z$-score. Under such conditions, the risk was 2.19 (95\%CI: 1.07-4.45) times greater for these as compared to eutrophic children. This finding is of great epidemiological importance, particularly because a major decline has recently been detected in severe and moderate malnutrition among children in Salvador, based on both the weightfor-age and height-for-age anthropometric indices 7 . This decrease may have been due to interventions in the field of health, nutrition, and sanitation by government agencies and nongovernmental organizations. However, the evi- 
Adjusted odds ratio for the association between anemia and biological, nutritional, social, and environmental variables in preschool children in Salvador, Bahia, Brazil, 1996.

\begin{tabular}{|c|c|c|c|}
\hline \multirow[t]{2}{*}{ Variables } & \multicolumn{3}{|c|}{ Hemoglobin $(<11.0 \mathrm{~g} / \mathrm{dl})$} \\
\hline & adjusted OR* & $95 \% \mathrm{Cl}$ & p-value \\
\hline \multicolumn{4}{|l|}{ Age (months) } \\
\hline $0-6$ & 1.00 & & \\
\hline $6-12$ & 5.35 & $1.73-16.58$ & 0.005 \\
\hline $12-24$ & 4.78 & $1.97-11.57$ & 0.001 \\
\hline $24-60$ & 1.00 & $0.38-2.64$ & 0.997 \\
\hline \multicolumn{4}{|c|}{ Dietary iron density $(\mathrm{mg} / 100 \mathrm{kcalth})^{\star \star}$} \\
\hline$>0.6$ & 1.00 & & \\
\hline $0.6-0.4$ & 1.22 & $0.61-2.45$ & 0.568 \\
\hline$\leq 0.4$ & 3.11 & $1.13-8.58$ & 0.029 \\
\hline \multicolumn{4}{|c|}{ Distribution, dietary protein content $(\mathrm{g} / \text { day })^{\star \star}$} \\
\hline$>44.6$ & 1.00 & & \\
\hline $44.6-28.9$ & 1.39 & $0.61-3.20$ & 0.427 \\
\hline$\leq 28.8$ & 2.35 & $1.10-5.02$ & 0.028 \\
\hline \multicolumn{4}{|c|}{ Height-for-age indicator } \\
\hline$\geq-1$ (z score) & 1.00 & & \\
\hline$<-1$ (z score) & 219 & $1.07-4.45$ & 0.032 \\
\hline \multicolumn{4}{|c|}{$\begin{array}{l}\text { Index of household physical, environmental, } \\
\text { and sanitary conditions }\end{array}$} \\
\hline Good & 1.00 & - & - \\
\hline Fair & 1.70 & $1.10-2.61$ & 0.017 \\
\hline Precarious & 2.09 & $1.22-360$ & 0.009 \\
\hline
\end{tabular}

* adjusted for the other variables in the model; ${ }^{*}$ in tertiles; $95 \% \mathrm{Cl}=95 \%$ confidence interval.

dence indicates that such measures have failed to make a similar impact on the mild form of this disease. Taking the height-for-age indicator specifically, for the combined severe and moderate forms, one observes a low prevalence (3.0\%); however, the mild form shows a high prevalence $(15.1 \%)$. Evidence indicates that micronutrient deficiency (particularly of zinc, vitamin $\mathrm{A}$, and iron), especially during the phase of the rapid growth, can contribute to persistently high rates of the mild form of linear growth deficit 4 . This situation may explain the epidemiological malnutrition profile identified among children in Salvador.

This study's data also signal a dose-response relationship between anemia and precarious household physical, environmental, and sanitary conditions, as observed when the results were adjusted for the model's other variables.

A relationship has currently been well-established between adverse conditions in the social and economic 21 as well as sanitary envi- ronment 22 , constraining health and nutrition indicators in childhood. This scenario is reproduced particularly in geographic spaces marked by the same social and economic inequalities. In this sense, factors associated with anemia in children in Salvador were similar to those identified in preschool children in the State of Pernambuco, during the same period in which this study was conducted 2, indicating that children in Northeast Brazil are exposed to similar living conditions, determining a similar context for childhood health and nutrition.

Despite the limitation of the study's crosssectional design, which prevents all the potential confounding variables from being controlled, the results reinforce the evidence that the nutritional status of the children investigated here expresses the conditions in the social, economic, and sanitary environment and the food consumption pattern to which they are exposed. They are also highly significant in the epidemiological sense, to the extent that this 
deficit is associated with increased morbidity from infectious disease, thus jeopardizing childhood physical growth and learning 5 .

The high prevalence of anemia among preschool children in underdeveloped countries has motivated the implementation of policies to combat iron deficiency 5 , in Brazil as well as in other countries. However, these programs have shown little progress as compared to iodine and vitamin A supplementation pro-

\section{Resumo}

Este é um estudo transversal, realizado na cidade de Salvador, Bahia, Brasil, em 1996, envolvendo 603 préescolares com o objetivo de estimar a prevalência e identificar os fatores associados à ocorrência da anemia. A concentração da hemoglobina foi determinada utilizando-se o hemoglobinômetro (Hemocue). Níveis de hemoglobina abaixo de 11,0g/dl caracterizaram a anemia. Utilizou-se a análise de regressão logística para avaliar as associações de interesse. A prevalência da anemia foi de 46,3\%. As faixas etárias de 6 a 12 e 12 a 24 meses, a densidade de ferro e a quantidade de proteína, situados no terceiro tercil da distribuição de consumo e quaisquer níveis de inadequação da altura em relação à idade constituíram-se em fatores de risco para a ocorrência da anemia. Inadequadas condições físicas, sanitárias e ambientais do domicilio imprimiram riscos crescentes e significantes na ocorrência da anemia A anemia é um importante problema de saúde nas crianças investigadas. Melhorias das condições de moradia e da qualidade da dieta consumida podem contribuir para diminuir a ocorrência da enfermidade.

Anemia; Pré-escolar; Modelos Logísticos grams 1 . This fact may indicate that in addition to the logistic problems identified with the distribution of prophylactic doses of iron, measures to combat iron deficiency should also take into account the association between anemia, food intake, the child's anthropometric status, and the physical, sanitary, and environmental conditions in the household and surroundings.

\section{Contributors}

M. O. Assis participated in the elaboration of the design for the statistical analysis. Together with M. L. Barreto, M. S. Prado and L. M. P. Santos collaborated in the study design. A. M. O. Assis, M. S. Prado, L. M. P. Santos, L. R. Sampaio, and R. C. Ribeiro coordinated the field work. G. S. S. Gomes collaborated in the elaboration and implementation of the statistical analysis. N. S. Santos, V. A. Oliveira and L. P. M. Oliveira collaborated in the data collection, implementation, and interpretation of the results in the food consumption analysis A. M. O. Assis, M. L. Barreto, and M. S. Prado participated in the final version of the article. N. S. Santos, L. M. P. Santos, L. R. Sampaio, R. C. Ribeiro, L. P. M. Oliveira, and V. A. Oliveira conducted the final revision. 


\section{References}

1. Administrative Committee on Coordination/Sub Committee on Nutrition. 4th Report on the world nutrition situation. Nutrition throughout the life cycle. Geneva: Administrative Committee on Coordination/Sub Committee on Nutrition; 2000.

2. Osório MM, Lira PI, Ashworth A. Factors associated with $\mathrm{Hb}$ concentration in children aged 6-59 months in the State of Pernambuco, Brazil. Br J Nut 2004; 91:307-15.

3. Monteiro CA, Szarfarc SC, Mondini L. Tendência secular da anemia na infância na cidade de São Paulo (1984-1996). Rev Saúde Pública 2000; 34: 62-72.

4. Administrative Committee on Coordination/Sub Committee on Nutrition and Poverty. Geneva: Administrative Committee on Coordination/Sub Committee on Nutrition; 1997. (Report Nutrition Policy Paper no 16).

5. World Health Organization. Iron deficiency anaemia: assessment, prevention and control. A guide for programme managers. Geneva: World Health Organization; 2001. (Technical Report WHO/NHD/01.3).

6. Administrative Committee on Coordination/Sub Committee on Nutrition. What works? A review of efficacy and effectiveness of nutrition interventions. Geneva: Administrative Committee on Coordination/Sub Committee on Nutrition; 2001.

7. Assis AMO, Barreto ML, Santos LMP, Sampaio LR, Magalhães LP, Prado MS, et al.. Condições de vida, saúde e nutrição na infância em Salvador. Salvador: Bureau Editora; 2000.

8. Fundação Instituto Brasileiro de Geografia e Estatística. Censo Demográfico - Bahia. Rio de Janeiro: Fundação Instituto Brasileiro de Geografia e Estatística; 1991.

9. Paim JS. Análise da situação de saúde no Município de Salvador, segundo as condições de vida. Salvador: Organização Pan-Americana da Saúde/ Conselho Nacional de Ciência e Tecnologia; 1995.

10. Willett W. Nutritional epidemiology. New York: Oxford University Press; 1990.

11. Magalhães LP, Oliveira VA, Santos JM. Guia para estimar consumo alimentar. Salvador: Núcleo de Pesquisa de Nutrição e Epidemiologia, Universidade Federal da Bahia; 1996.
12. Organización Mundial de la Salud. Medición del cambio del estado nutricional. Geneva: Organización Mundial de la Salud; 1983.

13. Wintrobe M, Lee GR, Bogs TR, Bithell TC, Foerster J, Athens J, et al. Clinical hematology. 8th Ed. Philadelphia: Lea \& Febiger; 1981.

14. National Center for Health Statistics. Growth curves for children birth-18 years. Washington DC: National Center for Health Statistics; 1977. (Vital and Health Statistics Series 11).

15. World Health Organization. Global database on child growth and malnutrition. Program of Nutrition and Family and Reproductive Health. Geneva: World Health Organization; 1997.

16. de Onis, M, Frongillo EA, Blössner M. Is malnutrition declining? An analysis of changes in levels of child malnutrition since 1980. Bull World Health Organ 2000; 78:1222-33.

17. Pelletier DL. The relationship between child anthropometry and mortality in developing countries: Implications for policy, programs and future research. J Nutr 1994; 124 Suppl:2047S-81S.

18. Issler RM, Giugliani ER, Kreutz GT, Meneses CF, Justo EB, Kreutz VM, et al. Poverty levels and children's health status: study of risk factors in an urban population of low socioeconomic level. Rev Saúde Publica 1996; 30:506-11.

19. Kish L. Survey sample. New York: John Wiley \& Sons; 1965.

20. World Health Organization. Complementary feeding of children in development countries: a review of current scientific knowledge. Geneva: World Health Organization; 1998. (Technical Report WHO/NUT/98.1).

21. Victora CG, Wagstaff A, Schellenberg JA, Gwatkin D, Claeson M, Habicht JP. Applying an equity lens to child health and mortality: more of the same is not enough. Lancet 2003; 362:233-41.

22. Checkey W, Gilman RH, Black RE, Epstein LD, Cabrera L, Sterling CR, et al. Effect of water and sanitation on childhood health in a poor Peruvian peri-urban community. Lancet 2004; 363:112-8.

\footnotetext{
Submitted on $23 /$ Jun/2003

Final version resubmitted on 18/Feb/2004

Approved on 01/Mar/2004
} 